\title{
Green tea extract and its major constituent epigallocatechin-3-gallate inhibit growth and halitosis-related properties of Solobacterium moorei
}

\author{
Marie-Pierre Morin', Telma Blanca Lombardo Bedran², Jade Fournier-Larente' ${ }^{1}$, Bruno Haas', Jabrane Azelmat ${ }^{1}$ \\ and Daniel Grenier ${ }^{1 *}$
}

\begin{abstract}
Background: Solobacterium moorei is a volatile sulfide compound (VSC)-producing Gram-positive anaerobic bacterium that has been associated with halitosis. The aim of this study was to investigate the effects of green tea extract and its major constituent epigallocatechin-3-gallate (EGCG) on growth and several halitosis-related properties of S. moorei.

Methods: A microplate dilution assay was used to determine the antibacterial activity of green tea extract and EGCG against S. moorei. Their effects on bacterial cell membrane integrity were investigated by transmission electron microscopy and a fluorescence-based permeability assay. Biofilm formation was quantified by crystal violet staining. Adhesion of FITC-labeled S. moorei to oral epithelial cells was monitored by fluorometry. The modulation of $\beta$-galactosidase gene expression in S. moorei was evaluated by quantitative RT-PCR.
\end{abstract}

Results: The green tea extract as well as EGCG inhibited the growth of S. moorei, with MIC values of $500 \mathrm{and} 250 \mathrm{\mu g} / \mathrm{ml}$, respectively. Transmission electron microscopy analysis and a permeabilization assay brought evidence that the bacterial cell membrane was the target of green tea polyphenols. Regarding the effects of green tea polyphenols on the S. moorei colonization properties, it was found that biofilm formation on EGCG-treated surfaces was significantly affected, and that green tea extract and EGCG can cause the eradication of pre-formed S. moorei biofilms. Moreover, both the green tea extract and EGCG were found to reduce the adherence of $S$. moorei to oral epithelial cells. The $\beta$-galactosidase activity of S. moorei, which plays a key role in VSC production, was dose-dependently inhibited by green tea polyphenols. In addition, EGCG at $1 / 2$ MIC significantly decreased the $\beta$-galactosidase gene expression.

Conclusion: Our study brought evidence to support that green tea polyphenols possess a number of properties that may contribute to reduce $S$. moorei-related halitosis. Therefore, these natural compounds may be of interest to be used to supplement oral healthcare products.

Keywords: Green tea, EGCG, Halitosis, Solobacterium moorei

\section{Background}

Tea, an aqueous aromatic infusion of dried leaves of the plant Camellia sinensis, is the most widely consumed beverage in the world after water. More specifically, green tea is made of non-fermented leaves and has a high catechin content (flavan-3-ols), including epigallocatechin-3-gallate (EGCG) that represents about $59 \%$ of total catechins [1]. There is an emerging body of evidence supporting that

\footnotetext{
* Correspondence: daniel.grenier@greb.ulaval.ca

${ }^{1}$ Groupe de Recherche en Écologie Buccale, Faculté de Médecine Dentaire, Université Laval, 2420 rue de la Terrasse, G1V 0A6, Quebec City, QC, Canada Full list of author information is available at the end of the article
}

green tea polyphenols may contribute to reducing the risk and/or severity of many systemic conditions and diseases, such as diabetes, cardiovascular disease and cancer [1-3]. The beneficial properties of green tea polyphenols have been mostly associated to their anti-inflammatory, antimutagenic, and anti-oxidative properties [1-3].

Epidemiological and clinical studies have provided some evidence that green tea consumption may have potential oral health benefits thus resulting in a decreased incidence/severity of dental caries and periodontal diseases, the two most common oral infections [4-8]. On the one hand, the ability of green tea polyphenols to 
inhibit Streptococcus mutans growth, biofilm formation, and acid production may contribute to its beneficial effects for dental caries [9-11]. On the other hand, the positive impact of green tea polyphenols for periodontal diseases may be associated to their ability to inhibit growth, adherence, and protease activity of Porphyromonas gingivalis $[12,13]$, a major pathogen causing chronic periodontitis. Moreover, it has been shown that green tea polyphenols can exert anti-inflammatory properties by decreasing the secretion of interleukin-6, interleukin-8, and $\mathrm{C}-\mathrm{C}$ motif chemokine ligand 5 (CCL5) by $P$. gingivalisstimulated gingival epithelial cells [13]. Recently, our laboratory reported that green tea extract and its major constituent EGCG induce the secretion of $\beta$-defensins, a family of antimicrobial peptides, by gingival epithelial cells [14]. This property of green tea polyphenols to increase epithelial $\beta$-defensin secretion may have a positive impact by strengthening the epithelial antimicrobial barrier.

Halitosis (oral malodor) that affects a large proportion of the population is a condition in which a person suffers from bad breath. Bad breath originating from the oral cavity is due to volatile sulfide compounds (VSCs) generated through bacterial metabolism [15,16]. The dorso-posterior region of the tongue is a major source of oral malodor [17]. More particularly, proteolytic bacteria found in tongue coating degrade proteins leading to the production of cysteine and methionine which are further processed into hydrogen sulfide and methylmercaptan by specific bacterial species $[15,16]$. The basic treatment for oral malodor includes mechanical removal of the tongue coating with toothbrushes or tongue scrapers [18]. In addition, the use of oral care products supplemented with chemicals effective in preventing bacterial growth (chlorhexidine, cetylpyridinium chloride, triclosan, essential oils) or neutralizing VSCs (chlorine dioxide, zinc salts) can improve the condition significantly [18]. Few studies have also brought evidence that green tea polyphenols may be effective in reducing halitosis $[19,20]$. The efficacy of green tea polyphenols for halitosis has been related to their ability to modify VSCs that results in a deodorant activity $[19,21]$.

The Gram-positive anaerobic bacterium Solobacterium moorei has been specifically associated with oral malodor since it has been reported to be present in subjects with halitosis but not in control subjects [22-24]. As a matter of fact, Haraszthy et al. [22] detected S. moorei in $100 \%$ of the 21 subjects with halitosis compared to only $14 \%$ of the control subjects. Recently, Vancauwenberghe et al. [25] reported a significant correlation between $S$. moorei, tongue coating and total VSCs. In a previous study, we showed that $S$. moorei can be a major source of malodorous compounds by producing VSCs from mucin through a process involving the cell-associated $\beta$ galactosidase activity of the bacterium and an exogenous source of proteases [26]. In this study, we investigated the effects of a green tea extract and its major constituent EGCG on growth and several halitosis-related properties of S. moorei.

\section{Methods}

\section{Green tea extract and epigallocatechin-3-gallate}

The commercial green tea extract (Organic Herb Inc., Changsha, China) used in this study had a polyphenol content $\geq 98 \%$, including $45 \%$ EGCG, according to the company's data sheet. A stock solution was freshly prepared by dissolving $20 \mathrm{mg}$ of powder in one $\mathrm{ml}$ of sterile warm distilled water and filtering the solution through a $0.2 \mu \mathrm{m}$-pore membrane filter. EGCG (Sigma-Aldrich Canada Ltd, Oakville, ON, Canada), the major catechin in green tea, was also dissolved in sterile distilled water at a concentration of $5 \mathrm{mg} / \mathrm{ml}$ and was filter sterilized as above.

\section{Bacteria and culture conditions}

S. moorei CH8-20, kindly provided by V. Haraszthy (The State University of New York at Buffalo), was used in this study. This strain was isolated from the dorsal surface of the tongue in a subject with halitosis [22]. Bacteria were routinely grown in Todd-Hewitt Broth (THB) medium (BBL Microbiology Systems, Cockeysville, MD, USA) supplemented with $0.001 \%$ hemin, $0.0001 \%$ vitamin K, $0.5 \%$ Tween- $80,0.2 \%$ yeast extract, and $1 \%$ glucose. Incubation was carried out at $37^{\circ} \mathrm{C}$ under anaerobic conditions $\left(\mathrm{N}_{2}: \mathrm{H}_{2}: \mathrm{CO}_{2} / 75: 10: 15\right)$.

\section{Determination of minimal inhibitory concentrations and minimal bactericidal concentrations}

Minimal inhibitory concentrations (MICs) and minimal bactericidal concentrations (MBCs) were determined using a microbroth dilution assay as described in a previous study [27]. Penicillin G was used as reference compound. MIC values $(\mu \mathrm{g} / \mathrm{ml})$ of compounds were determined as the lowest concentration at which no growth occurred. To determine $\mathrm{MBC}$ values $(\mu \mathrm{g} / \mathrm{ml})$, aliquots $(5 \mu \mathrm{l})$ of each well showing no visible growth were spread on bloodsupplemented THB agar plates, which were incubated for 3 days at $37^{\circ} \mathrm{C}$. MBCs of compounds were determined as the lowest concentration at which no colony formation occurred. The MIC and MBC values were determined in three independent experiments.

\section{Transmission electron microscopy analysis of bacterial cells}

S. moorei was grown as above, harvested by centrifugation, and washed once in $50 \mathrm{mM}$ phosphate-buffered saline $\mathrm{pH} 7.2$ (PBS). Cells were suspended in PBS at an $\mathrm{OD}_{660}$ of 0.5 and incubated in the presence of either green tea extract $(500 \mu \mathrm{g} / \mathrm{ml})$ or EGCG $(250 \mu \mathrm{g} / \mathrm{ml})$ at room temperature for $4 \mathrm{~h}$. Thereafter, bacteria were fixed 
for $2 \mathrm{~h}$ at room temperature in $0.1 \mathrm{M}$ cacodylate buffer ( $\mathrm{pH} 7)$ containing $5 \%$ glutaraldehyde and $0.15 \%$ ruthenium red. Cells were then reacted with polycationic ferritin $(1 \mathrm{mg} / \mathrm{ml})$ and processed as described by Vanrobaeys et al. [28]. Thin sections were examined using a JEOL 1230 transmission electron microscope at an accelerating voltage of $80 \mathrm{kV}$.

\section{Cell membrane permeability assay}

The effect of green tea extract and EGCG on cell membrane permeability of $S$. moorei was determined using the intracellular dye calcein acetoxymethyl ester (calcein-AM) (Sigma-Aldrich Canada Ltd), as previously described [29]. Briefly, S. moorei cells were suspended in PBS at an $\mathrm{OD}_{660}$ of 0.1 and one ml was incubated in the presence of $5 \mu \mathrm{l}$ of $1 \mathrm{mM}$ calcein-AM for $4 \mathrm{~h}$ at room temperature. Bacteria were then washed twice and suspended in $2 \mathrm{ml}$ of PBS. Calcein-AM-loaded bacteria were dispensed $(100 \mu \mathrm{l})$ into wells of a black 96-well microplate, and incubated at room temperature in the presence of either green tea extract $(500 \mu \mathrm{g} / \mathrm{ml})$ or EGCG $(250 \mu \mathrm{g} / \mathrm{ml})$. The release of calcein-AM resulting from cell damages was monitored every 10 min during 160 min using a microplate reader at excitation wavelength of $485 \mathrm{~nm}$ and emission wavelength of $530 \mathrm{~nm}$. PBS was used as negative control while heat-treated $\left(80^{\circ} \mathrm{C} / 10 \mathrm{~min}\right)$ cells were used as positive control.

\section{Biofilm formation and desorption}

The effect of treating wells of a microplate with either green tea extract or EGCG (1000 to $3.125 \mu \mathrm{g} / \mathrm{ml}$ ) for $2 \mathrm{~h}$ (room temperature) on biofilm formation by $S$. moorei was assessed. Wells treated with PBS served as control. Following treatment, a 24-h culture of S. moorei was diluted in fresh broth medium to obtain an $\mathrm{OD}_{660}$ of 0.1 . Samples $(200 \mu \mathrm{l})$ were added to treated wells of a $96-$ well microplate. After incubation for $48 \mathrm{~h}$ at $37^{\circ} \mathrm{C}$ under anaerobic conditions, spent media and free-floating bacteria were removed by aspiration using a $26 \mathrm{~g}$ needle. The wells were washed once with PBS and the S. moorei biofilms were stained with $0.05 \%$ crystal violet $(100 \mu \mathrm{l})$ for $15 \mathrm{~min}$. The wells were washed four times with PBS to remove unbound crystal violet dye and dried for $2 \mathrm{~h}$ at $37^{\circ} \mathrm{C}$. After adding $100 \mu \mathrm{l}$ of $95 \%(\mathrm{v} / \mathrm{v})$ ethanol to each well, the plate was shaken for $10 \mathrm{~min}$ to release the stain from the biofilms and the absorbance at $550 \mathrm{~nm}\left(\mathrm{~A}_{550}\right)$ was recorded. In addition, the capacity of green tea extract and EGCG to promote biofilm desorption was investigated. Briefly, 48-h pre-formed $S$. moorei biofilms in microplate were treated for $2 \mathrm{~h}$ under anaerobiosis with either green tea extract or EGCG (1000 to $31.25 \mu \mathrm{g} / \mathrm{ml}$ ). Following these treatments, the biofilms were washed twice with PBS and stained with crystal violet as above. Biofilms treated with PBS were used as control.

\section{Adherence assay to oral epithelial cells}

$S$. moorei cells cultivated as above were labeled with fluorescein isothyocyanate (FITC) as previously reported [30]. The immortalized human oral epithelial cell line OBA-9 used in this study, kindly provided by Dr. Marcia Mayer (Departamento de Microbiologia, Institute of Biomedical Sciences, Universidade de São Paulo, São Paulo, Brazil), was initially described by Kusumoto et al. [31]. The epithelial cells were cultured (96-well microplate) in Keratinocyte-Serum Free Medium (K-SFM, Life Technologies Inc., Burlington, ON, Canada) containing insulin, epidermal growth factor, and fibroblast growth factor, and supplemented with $100 \mu \mathrm{g} / \mathrm{ml}$ of penicillin $\mathrm{G} /$ streptomycin at $37^{\circ} \mathrm{C}$ in a $5 \% \mathrm{CO}_{2}$ atmosphere until they reached confluence. The adherence assay of $S$. moorei to epithelial cells in the absence or presence of green tea extract or EGCG (200 to $3.125 \mu \mathrm{g} / \mathrm{ml}$ ) was carried out as described in a previous study [13]. After removing unbound bacteria and washing wells, the relative fluorescence units (RUF; excitation wavelength $495 \mathrm{~nm}$; emission wavelength $525 \mathrm{~nm}$ ) corresponding to the degree of bacterial adherence were determined using a microplate reader.

\section{Determination of $\beta$-galactosidase activity}

The effect of green tea extract and EGCG on cellassociated $\beta$-galactosidase activity of $S$. moorei was determined using the chromogenic substrate $o$-nitrophenyl- $\beta$-D-galactopyranoside (Sigma-Aldrich Canada Ltd). Briefly, cells of $S$. moorei $\left(\mathrm{OD}_{660}=2.0\right.$ in PBS $)(100 \mu \mathrm{l})$ were incubated with $25 \mu \mathrm{l}$ of substrate $(2 \mathrm{mg} / \mathrm{ml})$ and $25 \mu \mathrm{l}$ of green tea extract or EGCG (500 to $62.5 \mu \mathrm{g} / \mathrm{ml}$ ). The reaction mixtures were incubated at $37^{\circ} \mathrm{C}$ for $2 \mathrm{~h}$ and bacteria were removed by centrifugation prior to measure the absorbance at $405 \mathrm{~nm}\left(\mathrm{~A}_{405}\right)$.

\section{Determination of $\beta$-galactosidase gene expression by quantitative RT-PCR}

To investigate the effect of green tea extract and EGCG on $\beta$-galactosidase gene expression, $S$. moorei was grown to mid-log phase $\left(\mathrm{OD}_{660}=0.4\right)$ and then compounds were added at MIC (500 and $250 \mu \mathrm{g} / \mathrm{ml}$ for green tea extract and EGCG, respectively) and $1 / 2$ MIC (250 and $125 \mu \mathrm{g} / \mathrm{ml}$ for green tea extract and EGCG, respectively) prior to further incubate at $37^{\circ} \mathrm{C}$ for $8 \mathrm{~h}$. Bacteria were collected by centrifugation $(7000 \times g$ for $5 \mathrm{~min})$ and treated with an RNAprotect bacterial reagent (Qiagen Canada Inc., Montreal, QC, Canada). Bacterial cells were then lysed and RNA was isolated and purified using the RNeasy minikit (Qiagen Canada Inc.). The amounts of mRNA were quantified with the Experion ${ }^{\mathrm{Tm}}$ system (Bio-Rad Laboratories, Mississauga, ON, Canada). The reverse transcription-polymerase chain reaction (RT-PCR) to prepare cDNA was performed using the iScript ${ }^{\mathrm{TM}}$ 
Table 1 Minimal inhibitory concentration (MIC) and minimal bactericidal concentration (MBC) values of green extract, EGCG, and penicillin G for S. moorei

\begin{tabular}{lll}
\hline Compound & MIC $(\boldsymbol{\mu g} / \mathbf{m l})$ & MBC $(\boldsymbol{\mu g} / \mathbf{m l})$ \\
\hline Green tea extract & 500 & 4000 \\
EGCG & 250 & $>4000$ \\
Penicillin G & 0.098 & 6.25 \\
\hline
\end{tabular}

Reverse Transcription Supermix (Bio-Rad Laboratories) according to the manufacturer. Reverse transcription conditions were $5 \mathrm{~min}$ at $25^{\circ} \mathrm{C}, 30 \mathrm{~min}$ at $42^{\circ} \mathrm{C}$, and $5 \mathrm{~min}$ at $85^{\circ} \mathrm{C}$. Real-time PCR was used for quantification of $\beta$ galactosidase mRNA expression. 16S rRNA gene was used as an internal control for data normalization. The primers used for the quantitative RT-PCR were designed in this study and purchased from Life Technologies Inc. The sequences of the forward and reverse primers used were 16SSmo-F: 5'-CTGTAGAGATACAGTAGAGGTTATC-3' and 16SSmo-R: 5' -ATTGTAGTACGTGTGTAGCC-3', respectively, for $16 \mathrm{~S}$ rRNA gene, and 1477Bgal778: 5'-GTA TTCTTGATAGGTCTAAATCGTC-3' and 1477Bgal946R: 5' -CAGTAAATACATACAAACCATAACG-3', respectively, for $\beta$-galactosidase gene. Triplicate reactions were prepared with $10 \mu \mathrm{l}$ of PCR mixture containing $5 \mu \mathrm{l}$ of IQ SYBR Green Supermix (Bio-Rad Laboratories), $4 \mu \mathrm{l}$ of cDNA, $0.4 \mu \mathrm{l}$ of gene-specific primer, and $0.6 \mu \mathrm{l}$ of RNase- and DNase-free water. The samples were amplified using a Bio-Rad MyCycler ${ }^{\mathrm{Ta}}$ thermal cycler (Bio-Rad Laboratories). The amplification conditions were $95^{\circ} \mathrm{C}$ for $5 \mathrm{~min}$ followed by 35 cycles at $95^{\circ} \mathrm{C}$ for $1 \mathrm{~min}, 52^{\circ} \mathrm{C}$ for $1 \mathrm{~min}$ and $72^{\circ} \mathrm{C}$ for $30 \mathrm{~s}$. To validate the specificity of each primer pair, temperature curve analyses were performed.

\section{Statistical analysis}

All assays were performed in triplicate and the means \pm standard deviations were calculated. Differences between means were analyzed for statistical significance using the Student's $t$-test and were considered significant at $\mathrm{P}<0.01$.

\section{Results}

As reported in Table 1, both green tea extract and EGCG exhibited antibacterial activity towards $S$. moorei. On the one hand, the green tea extract had a MIC of $500 \mu \mathrm{g} / \mathrm{ml}$ while the MBC was $4000 \mu \mathrm{g} / \mathrm{ml}$. On the other hand, the MIC of EGCG was slightly lower at $250 \mu \mathrm{g} / \mathrm{ml}$ although the $\mathrm{MBC}$ was found to be $>4000 \mu \mathrm{g} / \mathrm{ml}$. As expected, penicillin $G$ used as a reference control showed much lower values of MIC $(0.098 \mu \mathrm{g} / \mathrm{ml})$ and $\mathrm{MBC}$ $(6.25 \mu \mathrm{g} / \mathrm{ml})$.
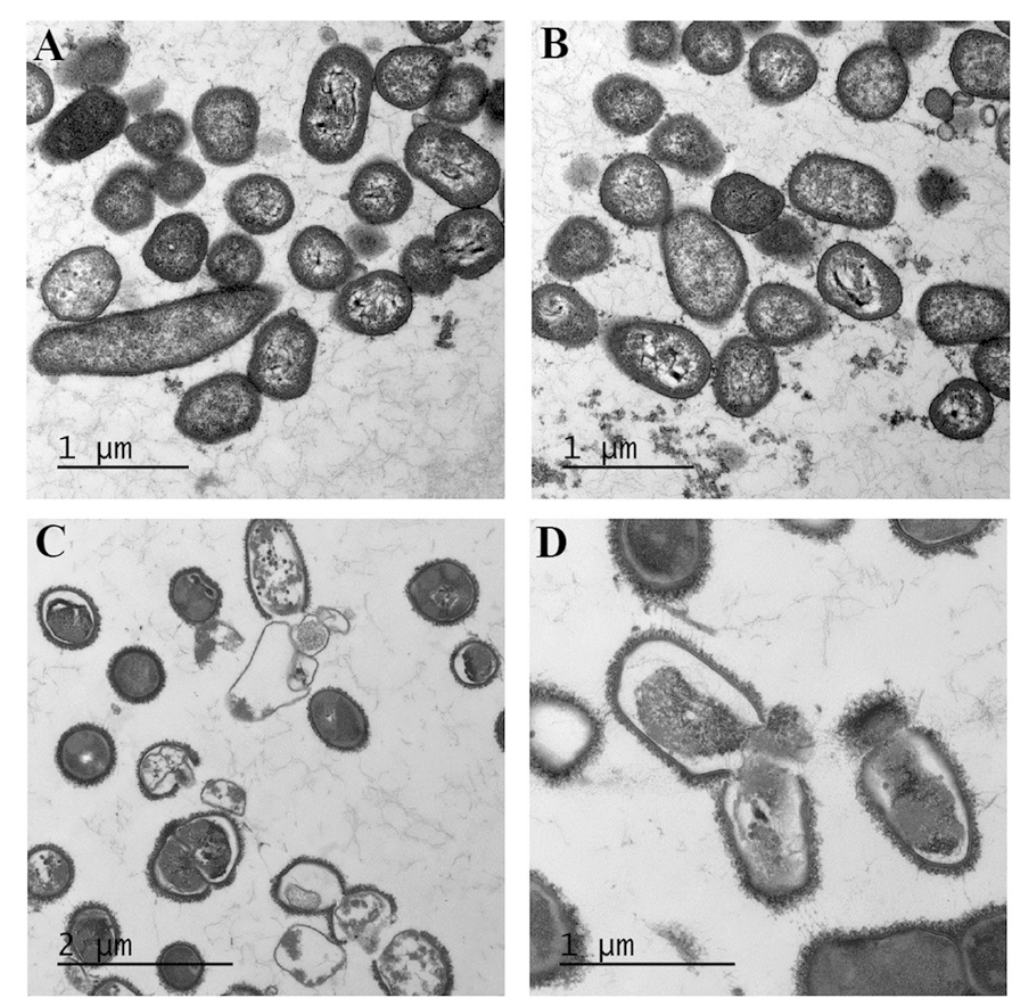

Figure 1 Transmission electron microscopy analysis of S. moorei. Panel A: Control untreated bacteria. Panel B: Bacteria treated (4 h) with green tea extract $(500 \mathrm{\mu g} / \mathrm{ml})$. Panels $\mathbf{C}$ and $\mathbf{D}$ : Bacteria treated $(4 \mathrm{~h})$ with EGCG $(250 \mathrm{\mu g} / \mathrm{ml})$. 
The effect of green tea polyphenols on the cell integrity of $S$. moorei was evaluated by transmission electron microscopy (Figure 1). The ultrastructure of $S$. moorei cells treated with green tea extract at the MIC $(500 \mu \mathrm{g} / \mathrm{ml})$ was not obviously affected compared to control cells (Figure 1A,B). However, in the electron micrographs of EGCG-treated $S$. moorei cells, severe ultrastructural damages were observed, which result in breakdown of the cytoplasmic membrane and cell wall with leakage of the cytoplasmic content (Figure 1C,D). In order to further investigate the effects of green tea polyphenols on the cytoplasmic membrane of $S$. moorei, the fluorescent dye calcein-AM was used. The addition of green tea extract or EGCG, both at MIC, to calcein-AM-loaded S. moorei cell suspensions caused a time-dependent release of fluorescence (Figure 2). The release of calcein-AM induced by green tea extract was more significant compared to EGCG.

When growth of $S$. moorei was carried out in the presence of either green tea extract or EGCG, no specific anti-biofilm effect was observed; the decreased biofilm formation was related to growth inhibition caused by the green tea polyphenols (data not shown). However, as reported in Figure 3, a pre-treatment of the polystyrene surfaces of the microplate with EGCG was found to dose-dependently reduce biofilm formation. Such treatment did not affect bacterial growth. More specifically, pretreating the polystyrene wells with EGCG at $500 \mu \mathrm{g} / \mathrm{ml}$ reduced S. moorei biofilm formation by $52 \%$. Although treatment of wells with the highest concentration of the green tea extract decreased biofilm formation by S. moorei, the inhibition was not significant.

The ability of green tea polyphenols to induce desorption of a pre-formed $S$. moorei biofilm was then investigated. EGCG and to a lesser extent green tea extract were found to dose-dependently desorb biofilms of $S$. moorei following an exposition of $2 \mathrm{~h}$ (Figure 4). This effect was found to be more pronounced for EGCG. At $125 \mu \mathrm{g} / \mathrm{ml}$, EGCG completely eradicated S. moorei biofilms, while at the same concentration the green tea extract had no significant effect.

Using fluorescein-labelled bacterial cells, S. moorei was found to adhere to oral epithelial cells (Figure 5). When

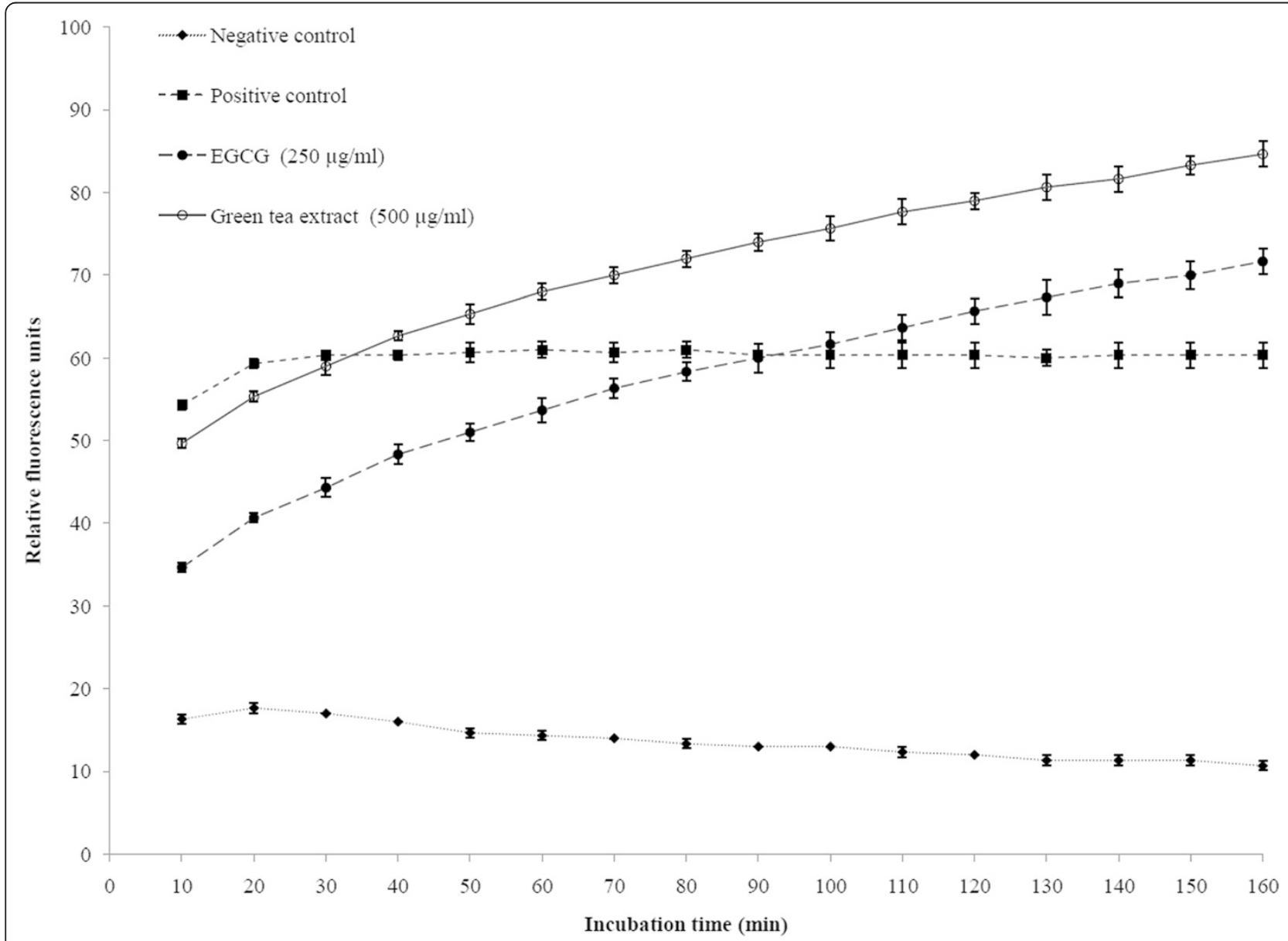

Figure 2 Time course of green tea extract- and EGCG-induced release of calcein-AM from S. moorei cells. Cells treated with PBS or heat $\left(80^{\circ} \mathrm{C} / 10 \mathrm{~min}\right)$ were used as negative and positive controls, respectively. Data are expressed as means \pm standard deviations. 


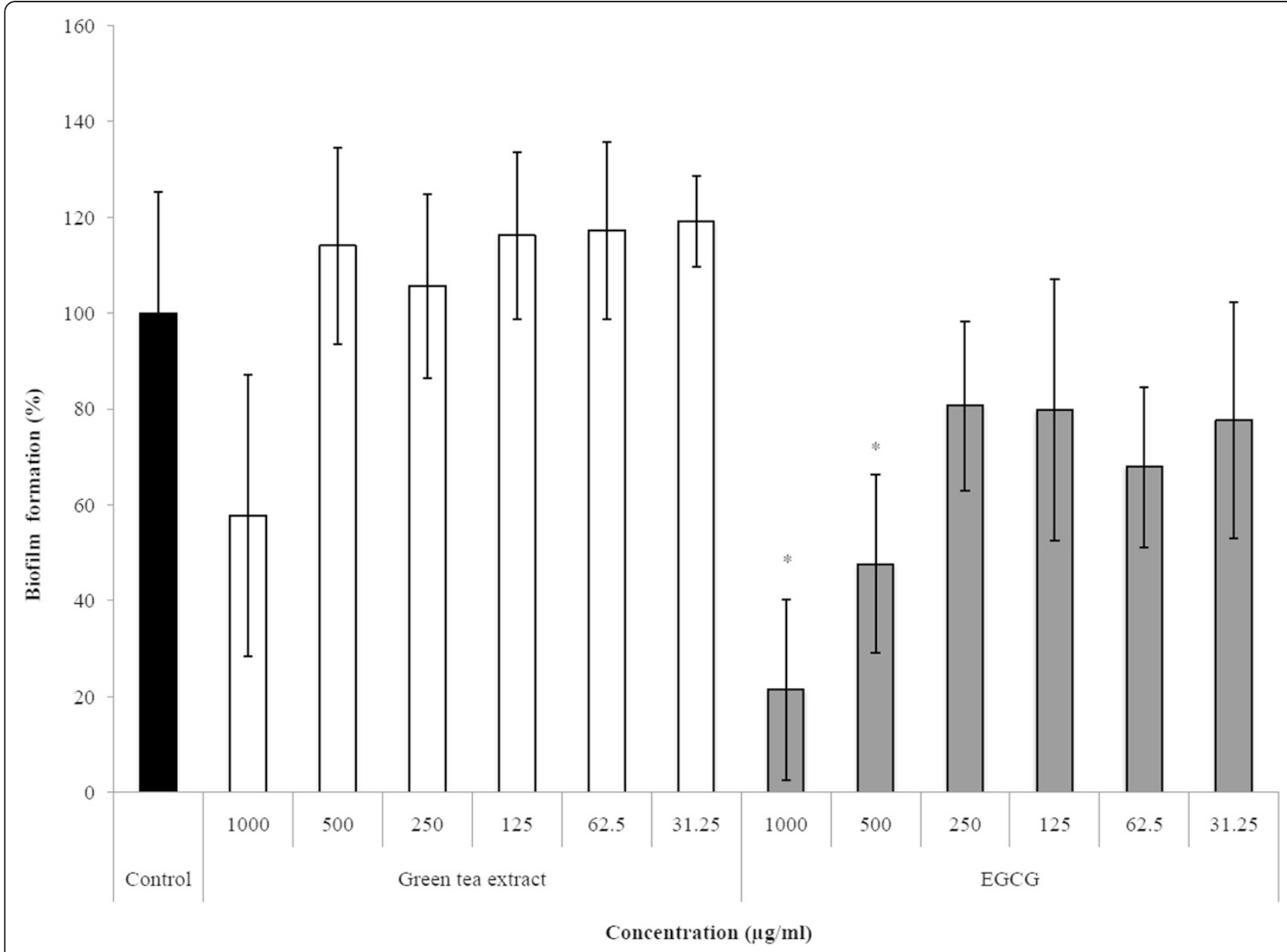

Figure 3 Effect of green tea extract and EGCG surface pre-treatments on biofilm formation by S. moorei in a microplate assay model. A relative value of $100 \%$ was assigned to control in which wells were pre-treated with PBS. Data are expressed as means \pm standard deviations. *, significant inhibition $(P<0.01)$ compared to control.

the adherence assay was performed in the presence of either green tea extract or EGCG, the adherence of S. moorei to oral epithelial cells was dose-dependently inhibited (Figure 5). At the highest concentration tested $(200 \mu \mathrm{g} / \mathrm{ml})$ the inhibition caused by EGCG was more significant.

Given that a previous study [26] showed that the $\beta$ galactosidase activity of $S$. moorei plays a key role in VSC production by the bacterium, we tested whether green tea polyphenols can inhibit the activity and gene expression of $\beta$-galactosidase. Table 2 reports that both green tea extract and EGCG, at a concentration $\geq 125 \mu \mathrm{g} / \mathrm{ml}$, caused a significant inhibition of $S$. moorei cell-associated $\beta$-galactosidase activity. More specifically, at $250 \mu \mathrm{g} / \mathrm{ml}$ green tea extract and EGCG caused an inhibition of $66.7 \%$ and $61.5 \%$, respectively. The effect of green tea polyphenols on $\beta$-galactosidase gene expression, as determined by quantitative PCR, is reported in Figure 6. On the one hand, when used at their MIC, both green tea extract and EGCG increased $\beta$-galactosidase gene expression. On the other hand, at $1 / 2$ of their MIC, while green tea extract had no effect, EGCG significantly decreased (33\%) the gene expression of $\beta$-galactosidase.

\section{Discussion}

Halitosis or oral malodor is in most cases caused by the production of VSCs, particularly methyl mercaptan and hydrogen sulfide, by specific bacterial species colonizing the gingival sulcus as well as the dorso-posterior region of the tongue [15]. It is estimated that up to half of the adult population is affected by halitosis, although epidemiologic studies using objective criteria showed that the prevalence may be lower [32-34]. Given its high prevalence in halitosis subjects, the Gram-positive strictly anaerobic bacterium $S$. moorei is considered as a key causative agent of halitosis [22-25]. In addition, it has also been associated with various types of dental infections such as endodontic infections [35,36], and refractory 


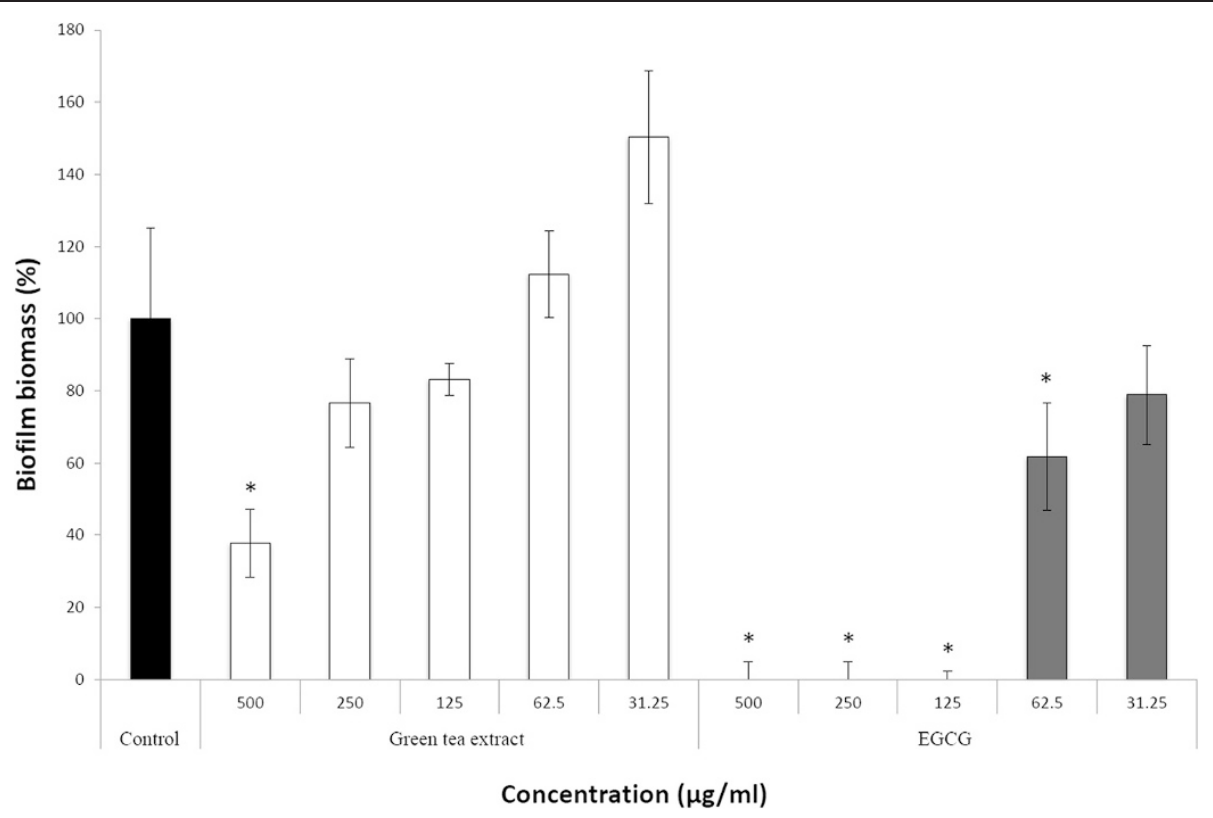

Figure 4 Effect of green tea extract and EGCG on desorption of a pre-formed S. moorei biofilm in a microplate assay model. A relative value of $100 \%$ was assigned to control in which biofilms were pre-treated with PBS. Data are expressed as means \pm standard deviations. *, significant inhibition $(P<0.01)$ compared to control.

periodontitis [37]. Considering the high incidence of halitosis in the general population, the strong association of $S$. moorei with this condition, and the growing interest of companies for natural plant molecules as efficacious and safe substances for oral care products (mints, gum, mouthwash, etc.), this study examined the effects of green tea extract and EGCG on growth and various halitosisrelated properties of $S$. moorei.

Green tea, the non-fermented form of tea, is considered as a functional food since it has positive health effects that extend beyond its nutritional value [8]. The most abundant polyphenol of green tea and the one that has been extensively studied is EGCG [1]. More specifically, Wu and Wei [4] reported that a cup of green tea (2.5 g of green tea leaves $/ 200 \mathrm{ml}$ of water) may contain up to $90 \mathrm{mg}$ of EGCG. Recent studies have suggested that green tea polyphenols may be regarded as molecules of interest for the management of oral diseases, including dental caries and periodontitis [4-13]. In this study, we uncovered new properties associated with green tea polyphenols, including EGCG, that support their potential for controlling halitosis.

We first showed that a green tea extract as well as its main constituent EGCG can efficiently inhibit the growth of S. moorei, with MICs of 500 and $250 \mu \mathrm{g} / \mathrm{ml}$, respectively. In regard to $\mathrm{MBCs}$, a value of $4000 \mu \mathrm{g} / \mathrm{ml}$ was obtained for green tea extract while that of EGCG was $>4000 \mu \mathrm{g} / \mathrm{ml}$. This suggests that green tea extract may contain additional bioactive components, in addition to EGCG, that can exert bactericidal action. These values are in agreement with those previously reported for other oral pathogens, including $P$. gingivalis [12]. Since the cell membrane is a target of many plant polyphenols, we investigated the effect of green tea polyphenols on $S$. moorei cell integrity by transmission electron microscopy and a membrane permeabilization assay. While the green tea extract did not markedly affect the bacterial ultrastructure, EGCG was found to induce major damages. Both green tea extract and EGCG appear to permeabilize the cell membrane resulting in calcein-AM leakage. Previous studies also reported that tea theaflavins and catechins can irreversibly damage the bacterial cytoplasmic membrane [38-40]. In regard to EGCG, it generates hydrogen peroxide in the lipid bilayer of the bacterial cytoplasmic membrane, resulting in leakage of intracellular materials [40]. Additional mechanisms by which green tea polyphenols inhibit the growth of $S$. moorei may be involved. For instance, Navarro-Martinez et al. [41] provided evidence that the antibacterial action of catechins against Stenotrophomonas maltophila, a Gram-negative opportunistic pathogen, is due to its ability to inhibit cytoplasmic dihydrofolate reductase. Dihydrofolate reductase reduces dihydrofolic acid to tetrahydrofolic acid, which is required by bacteria to synthetize purine, thymidylate, and nucleic acid precursors, which are very important for cell proliferation and growth.

Biofilm formation by $S$. moorei is likely a key step in halitosis. Although green tea polyphenols did not show any specific anti-biofilm effect on $S$. moorei, we showed that it can affect the biofilm via two mechanisms. First, 


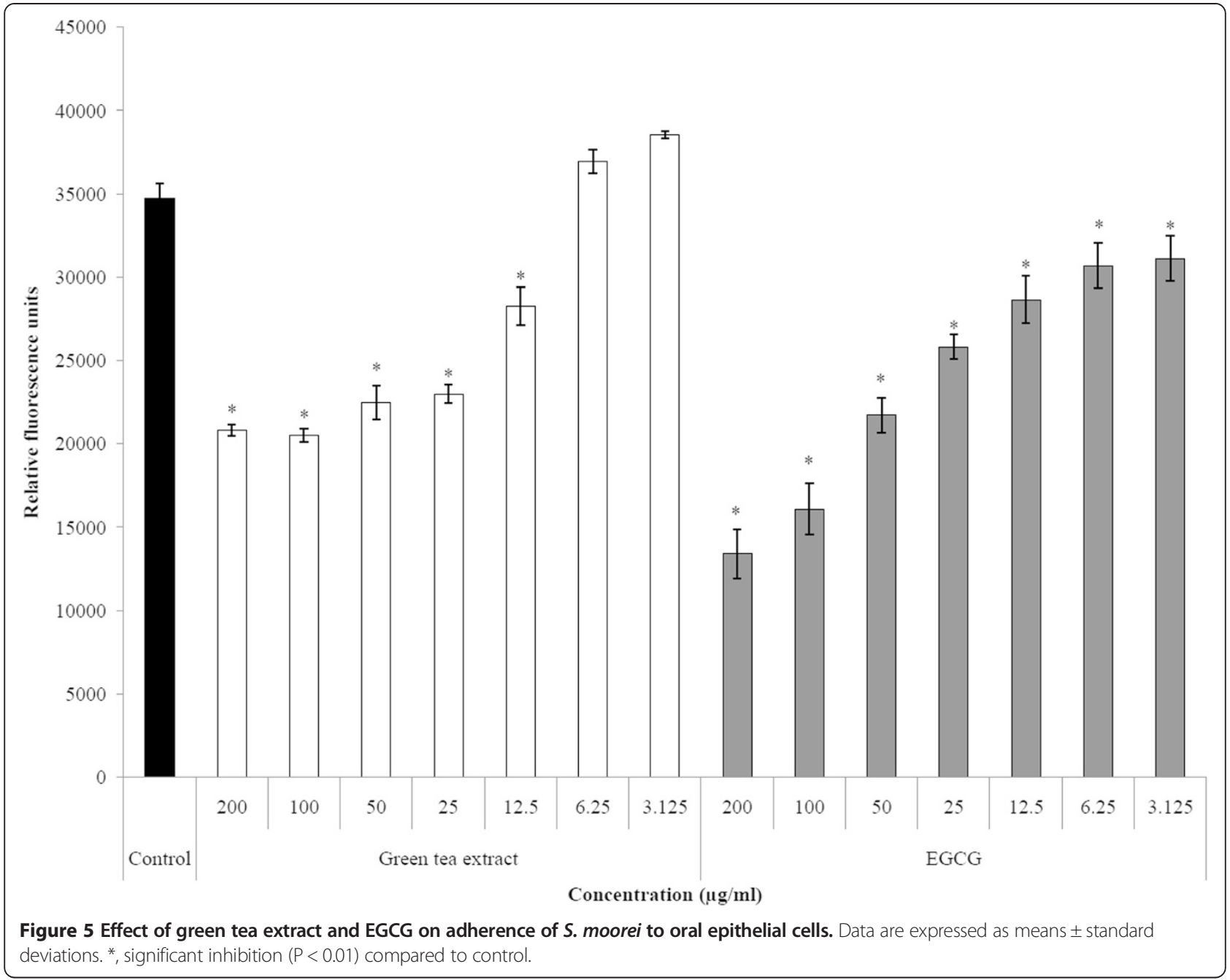

Table 2 Effect of green tea extract and EGCG on $\beta$-galactosidase activity of $S$. moorei

\begin{tabular}{lll}
\hline Compound & $\begin{array}{l}\text { \% inhibition of } \\
\boldsymbol{\beta} \text {-galactosidase activity }\end{array}$ \\
\hline None (control) & 0 \\
Green tea extract & $500 \mu \mathrm{g} / \mathrm{ml}$ & $75.4 \pm 9.3^{*}$ \\
& $250 \mu \mathrm{g} / \mathrm{ml}$ & $66.7 \pm 11.2^{*}$ \\
& $125 \mu \mathrm{g} / \mathrm{ml}$ & $43.6 \pm 13.7^{*}$ \\
& $62.5 \mu \mathrm{g} / \mathrm{ml}$ & $17.3 \pm 10.1$ \\
& $500 \mu \mathrm{g} / \mathrm{ml}$ & $72.1 \pm 9.8^{*}$ \\
EGCG & $250 \mu \mathrm{g} / \mathrm{ml}$ & $61.5 \pm 15.7^{*}$ \\
& $125 \mu \mathrm{g} / \mathrm{ml}$ & $53 \pm 9.5^{*}$ \\
& $62.5 \mu \mathrm{g} / \mathrm{ml}$ & $26.4 \pm 12.3$ \\
\hline
\end{tabular}

*Significantly different at $\mathrm{P}<0.01$ compared to control. the formation of biofilm by $S$. moorei on EGCG-treated surfaces was significantly affected. Second, both green tea extract and EGCG can cause the eradication of preformed S. moorei biofilms. The mechanism involved in biofilm desorption may be related to the ability of green tea polyphenols to alter the cell integrity of S. moorei.

Both the green tea extract and EGCG were also found to reduce the adherence of $S$. moorei to oral epithelial cells. This is in agreement with previous data reported by our laboratory showing that tea extracts (green, white, black, and oolong) can prevent the adherence of $P$. gingivalis to epithelial cells [13]. This inhibition may be related to the binding of green tea polyphenols to the bacterial cell surface thus altering the hydrophobicity or hiding adhesins.

In a previous study, we showed that $S$. moorei produces high levels of VSCs when cultivated in the presence of cysteine and that its cell-associated $\beta$-galactosidase is essential for VSC production from mucin [26]. This enzyme can deglycosylate salivary glycoproteins, which can be further degraded into peptides and amino acids by host and 


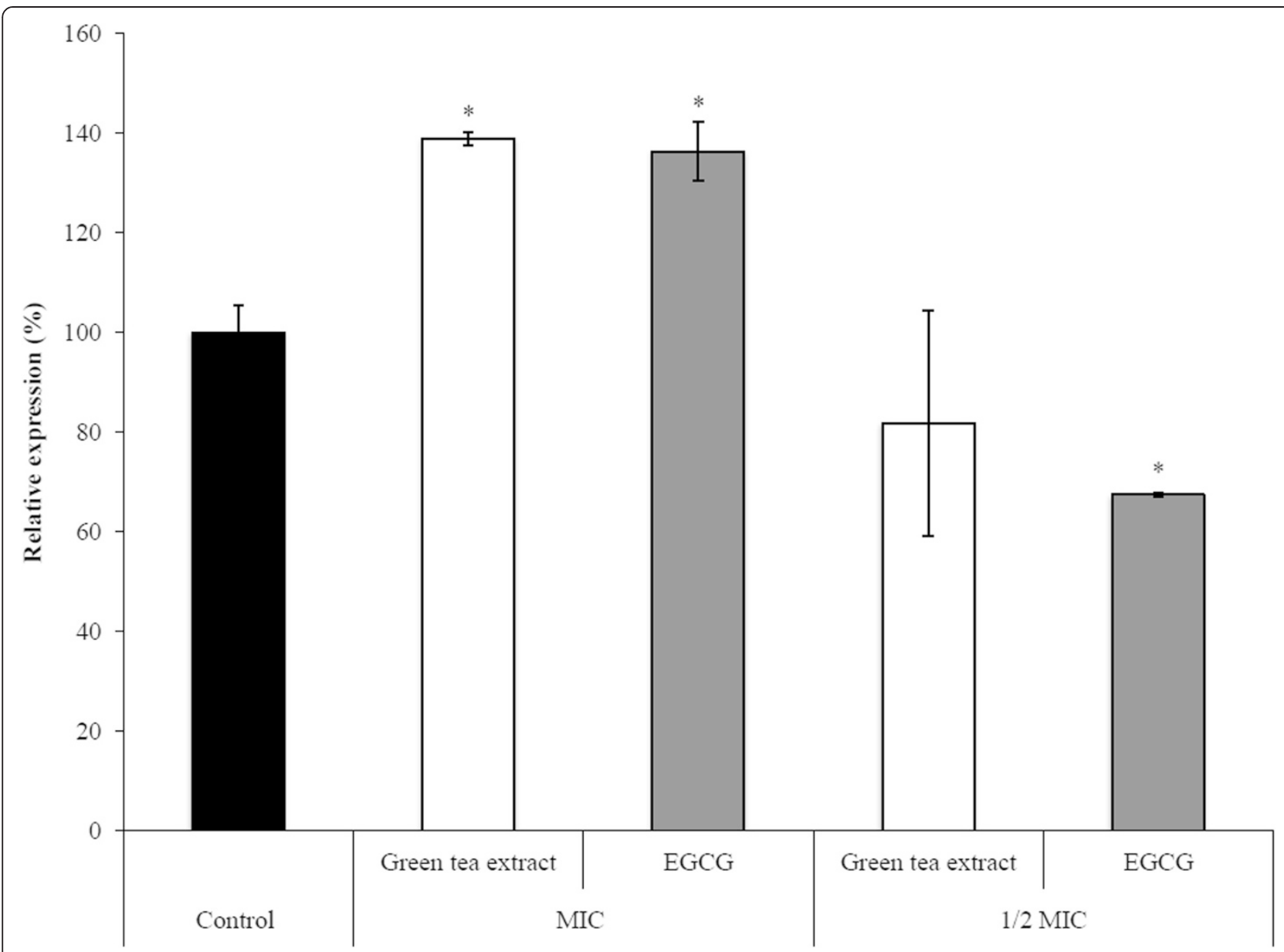

Figure 6 Effect of green tea extract and EGCG on mRNA expression of $\beta$-galactosidase gene in S. moorei. Bacteria were incubated (8 h) in the presence of compounds at MIC (500 and $250 \mu \mathrm{g} / \mathrm{ml}$ for green tea extract and EGCG, respectively), and 1 1 12 MIC ( 250 and $125 \mu \mathrm{g} / \mathrm{ml}$ for green tea extract and EGCG, respectively). Data are expressed as means \pm standard deviations. The expression was normalized to 165 rRNA. *, significantly different $(\mathrm{P}<0.01)$ compared to untreated control.

bacterial proteolytic enzymes prior to be transformed into VSCs. Interestingly, $\beta$-galactosidase activity in saliva has been associated with halitosis $[42,43]$. In this study, we showed that green tea extract and EGCG inhibit $\beta$ galactosidase activity of $S$. moorei, a property that may contribute to reduce oral malodor. The ability of green tea polyphenols to attenuate the $\beta$-galactosidase gene expression in $S$. moorei was also investigated. It was found that when used at MIC, both the green tea extract and EGCG up-regulate gene expression while at $1 / 2 \mathrm{MIC}$, EGCG significantly decreased the $\beta$-galactosidase gene expression whereas the green tea extract has no effect. Interestingly, $\mathrm{Xu}$ et al. [44] recently reported that subminimal inhibitory concentrations of EGCG suppress the gene expression of L-methionine- $\alpha$-deamino- $\gamma$-mercaptomethane lyase, a $P$. gingivalis enzyme involved in methyl mercaptan production.
Data presented in this study, strongly suggest that green tea polyphenols deserve to be considered as promising compounds for the management of halitosis. Additional polyphenols were also reported to possess beneficial properties in regard to halitosis. A licorice extract as well as isoflavanones (licoricidin and licorisoflavan A) isolated from this fraction were found to inhibit the growth of S. moorei, P. gingivalis, and Prevotella intermedia as well as to dosedependently reduce VSC production by these three bacterial species [45]. Moreover, Forrer et al. [46] recently reported that tea tree oil and alpha-bisabolol, plant essential oils contained in tongue gels and toothpastes, exert a bactericidal effect on S. moorei and therefore can be effective against halitosis. Further studies should evaluate whether combining the above natural compounds may result in synergistic effects. 


\section{Conclusions}

The initial therapy for halitosis consists in a mechanical scraping of the dorsum of the tongue to remove the biofilm also called tongue coating. An antimicrobial approach may also contribute to decrease tongue coating and reduce oral malodor. Our study brought evidence to support that green tea extract or EGCG possess a number of properties that may contribute to reduce $S$. moorei-related halitosis. Therefore, these natural compounds may be of interest to be used to supplement oral healthcare products.

\section{Competing interests}

The authors declare that they have no competing interests.

\section{Authors' contributions}

MPM, TBLB, JFL, BH, and JA performed all the experimental work. DG conceived the study design and prepared the final version of the manuscript. All authors read and approved the final manuscript.

\section{Acknowledgements}

We thank Violet Haraszthy (The State University of New York at Buffalo) for providing the strain of S. moorei, and Marcia Mayer for providing the OBA-9 epithelial cell line. This study was financially supported by the Laboratoire de Contrôle Microbiologique (Université Laval).

\section{Author details}

${ }^{1}$ Groupe de Recherche en Écologie Buccale, Faculté de Médecine Dentaire, Université Laval, 2420 rue de la Terrasse, G1V 0A6, Quebec City, QC, Canada. ${ }^{2}$ Department of Oral Diagnosis and Surgery, Araraquara Dental School, State University of São Paulo, São Paulo, Brazil.

Received: 2 April 2014 Accepted: 29 September 2014

Published online: 10 March 2015

\section{References}

1. Cabrera C, Artacho R, Giménez R. Beneficial effects of green tea - a review. J Am Coll Nutr. 2006;25:79-99.

2. Cooper R. Green tea and theanine: health benefits. Int J Food Sci Nutr. 2012;63:90-7.

3. Da Silva Pinta M. Tea: a new perspective on health benefits. Food Res Int. 2013;53:558-67.

4. Wu CD, Wei GX. Tea as a functional food for oral health. Nutrition. 2002;18:443-4.

5. Kushiyama M, Shimazaki Y, Murakami M, Yamashita Y. Relationship between intake of green tea and periodontal disease. J Periodontol. 2009;80:372-7.

6. Koyama Y, Kuriyama S, Aida J, Sone T, Nakaya N, Ohmori-Matsuda K, et al. Association between green tea consumption and tooth loss: cross-sectional results from the Ohsaki Cohort 2006 study. Prev Med. 2010;50:173-9.

7. Narotzki B, Reznick AZ, Aizenbud D, Levy Y. Green tea: a promising natural product in oral health. Arch Oral Biol. 2012;57:429-35.

8. Gaur S, Agnihotri R. Green tea: A novel functional food for the oral health of older adults. Geriatr Gerontol. 2013, doi:10.1111/ggi.12194

9. Xu X, Zhou XD, Wu CD. The tea catechin epigallocatechin gallate suppresses cariogenic virulence factors of Streptococcus mutans. Antimicrob Agents Chemother. 2011:55:1229-36.

10. Xu X, Zhou XD, Wu CD. Tea catechin epigallocatechin gallate inhibits Streptococcus mutans biofilm formation by suppressing gtf genes. Arch Oral Biol. 2012;57:678-83.

11. Hirasawa M, Takada K, Otake S. Inhibition of acid production in dental plaque by green tea catechins. Caries Res. 2006;40:265-70.

12. Sakanaka S, Aizawa M, Kim M, Yamamoto T. Inhibitory effects of green tea polyphenols on growth and cellular adherence of an oral bacterium Porphyromonas gingivalis. Biosci Biotechnol Biochem. 1996:60:745-9.

13. Zhao L, La VD, Grenier D. Antibacterial, antiadherence, antiprotease, and anti-inflammatory activities of various tea extracts: potential benefits for periodontal diseases. J Med Food. 2013;16:428-36.

14. Lombardo Bedran TB, Feghali K, Zhao L, Palomari Spolidorio DM, Grenier D. Green tea extract and its major constituent, epigallocatechin-3-gallate, induce epithelial beta-defensin secretion and prevent beta-defensin degradation by Porphyromonas gingivalis. J Periodontal Res. 2013, doi:10.1111/jre.12142.
15. Krespi YP, Shrime MG, Kacker A. The relationship between oral malodor and volatile sulfur compound-producing bacteria. Otolanyngology. 2006;135:671-6.

16. Hughes FJ, McNab R. Oral malodor - a review. Arch Oral Biol. 2008;53:S1-7.

17. Tonzetich J. Production and origin of oral malodor: a review of mechanisms and methods of analysis. J Periodontol. 1977;48:13-20.

18. Armstrong BL, Sensat ML, Stoltenberg J. Halitosis: a review of current literature. J Dent Hyg. 2010;84:65-74.

19. Lodhia P, Yaegaki K, Khakbaznejad A, Imai T, Sato T, Tanaka T, et al. Effect of green tea on volatile sulfur compounds in mouth air. J Nutr Sci Vitaminol. 2008:54:89-94.

20. Rassameemasmaung S, Phusudsawang P, Sangalungkarn V. Effect of green tea mouthwash on oral malodour. ISRN Prev Med. 2013, 975148. doi:10.5402/2013/975148.

21. Zeng QC, Wu AZ, Pika J. The effect of green tea extract on the removal of sulfur-containing oral malodour volatiles in vitro and its potential application in chewing gum. J Breath Res. 2010;4:036005.

22. Haraszthy VI, Gerber D, Clark B, Moses P, Parker C, Sreenivasan PK, et al. Characterization and prevalence of Solobacterium moorei associated with oral halitosis. J Breath Res. 2008:2:017002.

23. Haraszthy VI, Zambon JJ, Sreenivasan PK, Zambon MM, Gerber D, Rego R, et al. Identification of oral bacterial species associated with halitosis. J Am Dent Assoc. 2007;138:1113-20.

24. Kazor CE, Mitchell PM, Lee AM, Stokes LN, Loesche WJ, Dewhirst FE, et al. Diversity of bacterial populations on the tongue dorsa of patients with halitosis and healthy patients. J Clin Microbiol. 2003;41:558-63.

25. Vancauwenberghe F, Dadamio J, Laleman I, Van Tornout M, Teughels W, Coucke W, et al. The role of Solobacterium moorei in oral malodour. J Breath Res. 2013;7:046006

26. Tanabe SI, Grenier D. Characterization of volatile sulfur compound production by Solobacterium moorei. Arch Oral Biol. 2012;57:1639-43.

27. Villinski JR, Bergeron C, Cannistra JC, Gloer JB, Coleman CM, Ferreira D, et al. Pyrano-isoflavans from Glycyrrhiza uralensis with antibacterial activity against Streptococcus mutans and Porphyromonas gingivalis. J Nat Prod. 2014;77:521-6.

28. Vanrobaeys M, De Herdt P, Charlier G, Ducatelle R, Haesebrouck F. Ultrastructure of surface components of Streptococcus gallolytics (S. bovis) strains of differing virulence isolated from pigeons. Microbiology. 1999:145:335-42.

29. Huo L, Zhang K, Ling J, Peng Z, Huang X, Liu H, et al. Antimicrobial and DNA-binding activities of the peptide fragments of human lactoferrin and histatin 5 against Streptococcus mutans. Arch Oral Biol. 2011;56:869-76.

30. Marquis A, Genovese S, Epifano F, Grenier D. The plant coumarins auraptene and lacinartin as potential multifunctional therapeutic agents for treating periodontal disease. BMC Complement Altern Med. 2012;12:80.

31. Kusumoto Y, Hirano H, Saitoh K, Yamada S, Takedachi M, Nozaki T, et al. Human gingival epithelial cells produce chemotactic factors interleukin- 8 and monocyte chemoattractant protein-1 after stimulation with Porphyromonas gingivalis via Toll-like receptor 2. J Periodontol. 2004;75:370-9.

32. Rolph HJ, Lennon A, Riggio MP, Saunders WP, MacKenzie D, Coldero L, et al. Molecular identification of microorganisms from endodontic infections. J Clin Microbiol. 2001:39:3282-9.

33. Rôças IN, Hülsmann M, Siqueira Jr JF. Microorganisms in root canal-treated teeth from a German population. J Endod. 2008;34:926-31.

34. Colombo AP, Boches SK, Cotton SL, Goodson JM, Kent R, Haffajee AD, et al Comparisons of subgingival microbial profiles of refractory periodontitis, severe periodontitis, and periodontal health using the human oral microbe identification microarray. J Periodontol. 2009;80:1421-32.

35. Bornstein MM, Stocker BL, Seemann R, Bürgin WB, Lussi A. Prevalence of halitosis in young male adults: a study in swiss army recruits comparing self-reported and clinical data. J Periodontol. 2009:80:24-31.

36. Liu XN, Shinada K, Chen XC, Zhang BX, Yaegaki K, Kawaguchi Y. Oral malodor-related parameters in the Chinese general population. J Clin Periodontol. 2006;3:31-6

37. Miyazaki H, Sakao S, Katoh Y, Takehara T. Correlation between volatile sulphur compounds and certain oral health measurements in the general population. J Periodontol. 1995:66:679-84

38. Sirk TW, Friedman M, Brown EF. Molecular binding of black tea theaflavins to biological membranes: relationship to bioactivities. J Agric Food Chem. 2011;59:3780-7.

39. Ikigai H, Nakae T, Hara Y, Shimamura T. Bactericidal catechins damage the lipid bilayer. Biochim Biophys Acta. 1993;1147:132-6. 
40. Arakawa H, Maeda M, Okubo S, Shimamura T. Role of hydrogen peroxide in bactericidal action of catechin. Biol Pharm Bull. 2004;27:277-81.

41. Navarro-Martínez MD, Navarro-Perán E, Cabezas-Herrera J, Ruiz-Gómez J, García-Cánovas F, Rodríguez-López JN. Antifolate activity of epigallocatechin against Stenotrophomonas maltophila. Antimicrob Agents Chemother. 2005:49:2914-20.

42. Yoneda M, Masuo Y, Suzuki N, Iwamoto T, Hirofuji T. Relationship between the $\beta$-galactosidase activity in saliva and parameters associated with oral malodour. J Breath Res. 2010;4:017108

43. Sterer N, Bar-Ness Greenstein R, Rosenberg M. $\beta$-galactosidase activity in saliva is associated with oral malodour. J Dent Res. 2002;81:182-5.

44. Xu X, Zhou XD, Wu CD. Tea catechin EGCg suppresses the $\mathrm{mg} / \mathrm{gene}$ associated with halitosis. J Dent Res. 2010:89:1304-8.

45. Tanabe SI, Desjardins J, Bergeron C, Gafner S, Villinski JR, Grenier D. Reduction of bacterial volatile sulfur compound production by licoricidin and licorisoflavan A from licorice. J Breath Res. 2012;6:016006.

46. Forrer M, Kulik EM, Filippi A, Waltimo T. The antimicrobial activity of alpha-bisabolol and tea tree oil against Solobacterium moorei, a Gram-positive bacterium associated with halitosis. Arch Oral Biol. 2013;58:10-6.

\section{Submit your next manuscript to BioMed Central and take full advantage of:}

- Convenient online submission

- Thorough peer review

- No space constraints or color figure charges

- Immediate publication on acceptance

- Inclusion in PubMed, CAS, Scopus and Google Scholar

- Research which is freely available for redistribution 